Dipublikasikan

Badan Pelaksana Kuliah Kerja Nyata

Universitas Lampung

Sekretariat Badan Pelaksana Kuliah Kerja Nyata, Universitas Lampung, J. Prof. Dr. Soemantri Brojonegoro No. 1, Bandar Lampung 35145.

\title{
PELATIHAN PENYUSUNAN, PEMBUATAN, DAN PENGGUNAAN MEDIA PEMBELAJARAN BAGI GURU DI KECAMATAN LEMONG
}

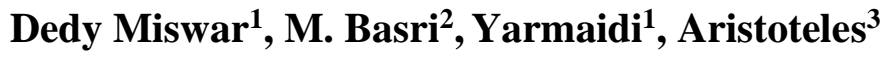 \\ ${ }^{1}$ Program Studi Pendidikan Geografi/Jurusan P. IPS/FKIP, Universitas Lampung \\ ${ }^{2}$ Program Studi Pendidikan Sejarah/Jurusan P. IPS/FKIP, Universitas Lampung \\ ${ }^{1}$ Program Studi Pendidikan Geografi/Jurusan P. IPS/FKIP, Universitas Lampung \\ ${ }^{3}$ Jurusan Ilmu Komputer/FMIPA, Universitas Lampung. \\ Penulis Korespodensi : dedy.miswar@ fkip.unila.ac.id
}

\begin{abstract}
Abstrak
Kemampuan dan keterampilan guru baik menggunakan maupun mengadakan media pembelajaran dalam proses belajar mengajar di dalam kelas bukan lagi merupakan suatu hal yang dapat diabaikan, akan tetapi ini merupakan suatu keharusan, mengingat dalam era pembangunan pendidikan di masa sekarang dan mendatang bertitik tolak pada kualitas keluarannya. Tujuan dalam pelatihan ini untuk meningkatkan pengetahuan, kemampuan dalam membuat dan kemampuan dalam menggunakan media pembelajaran. Metode yang digunakan dalam pelatihan ada 2, yaitu: ceramah (40\%) dan praktik (60\%) dengan jumlah peserta sebanyak 65 orang guru. Hasil pengabdian menunjukkan bahwa tingkat pemahaman berupa sikap, penguasaan, dan pembuatan media pembelajaran oleh peserta dilakukan dengan semangat yang ditunjukkan dari hasil post test yang memperoleh nilai yang baik para peserta sebanyak 65 orang atau $76,47 \%$.
\end{abstract}

Kata kunci: penyusunan, pembuatan, penggunaan, media pembelajaran.

\begin{abstract}
The ability and skills of teachers to both use and provide learning media in the teaching and learning process in the classroom are no longer something that can be ignored, but this is a must, considering that in the era of educational development in the present and future, it starts with the quality of its output. The purpose of this training is to increase knowledge, ability in making and the ability to use learning media. There are 2 methods used in the training, namely: lectures $(40 \%)$ and practice $(60 \%)$ with a total of 65 teachers. The results of the dedication showed that the level of understanding in the form of attitudes, mastery, and the making of learning media by the participants was carried out with enthusiasm as shown by the results of the post test which obtained good scores of participants as many as 65 people or $76.47 \%$.
\end{abstract}

Keywords: preparation, manufacture, use, learning media. 


\section{Jurnal Pengabdian Kepada Masyarakat BUGUH}

Dipublikasikan

Badan Pelaksana Kuliah Kerja Nyata

Universitas Lampung

Sekretariat Badan Pelaksana Kuliah Kerja Nyata, Universitas Lampung, J. Prof. Dr. Soemantri Brojonegoro No. 1, Bandar Lampung 35145.

\section{Pendahuluan}

Media merupakan alat yang harus ada apabila kita ingin memudahkan sesuatu dalam pekerjaan (Anshori, 2018). Media merupakan alat bantu yang dapat memudahkan pekerjaan. Setiap orang pasti ingin pekerjaan yang dibuatnya dapat diselesaikan dengan baik dan dengan hasil yang memuaskan (Luthfi, 2008; Hardianto, 2012).

Kata media itu sendiri berasal dari bahasa latin yang merupakan bentuk jamak dari kata "medium" yang berarti "pengantar atau perantara", dengan demikian dapat diartikan bahwa media merupakan wahana penyalur informasi belajar atau penyalur pesan (Hasanah, 2019).

Media yang difungsikan sebagai sumber belajar bila dilihat dari pengertian harfiahnya juga terdapat manusia didalamnya, benda, ataupun segala sesuatu yang memungkinkan untuk anak didik memperoleh informasi dan pengetahuan yang berguna bagi anak didik dalam pembelajaran, dan bagaimana dengan adanya media berbasis TIK tersebut, khususnya menggunakan presentasi power point dimana anak didik mempunyai keinginan untuk maju, dan juga mempunyai kreatifitas yang tinggi dan memuaskan dalam perkembangan mereka dikehidupan kelak (Duludu, 2017; Suardi, 2018).

Sasaran penggunaan media adalah agar anak didik mampu menciptakan sesuatu yang baru dan mampu memanfaatkan sesuatu yang telah ada untuk dipergunakan dengan bentuk dan variasi lain yang berguna dalam kehidupannya,. Dengan demikian mereka dengan mudah mengerti dan mamahami materi pelajaran yang disampaikan oleh guru kepada mereka (Susanto, 2014).

Media pembelajaran memiliki nilai yang sangat penting dalam dunia pendidikan, karena digunakan sebagai sarana untuk komunikasi didalam proeses belajar mengajar di sekolah. Dengan menggunakan media pembelajaran dapat meletakkan dasar-dasar yang kongkrit untuk berpikir secara riil, sehingga dengan demikian akan mendorong perhatian dan dapat menumbuhkan pemikiran yang berencana dan sistematis (Ekayani; Alwi, 2017). Pengalaman nyata melalui media juga dapat membantu dalam menciptakan kreatifitas, membuat pelajaran menjadi lebih menarik dan mantap, sehingga hal ini akan mendorong siswa untuk lebih giat belajar dan menyebabkan prestasi belajarnya lebih baik. Jadi jelaslah bahwa media pembelajaran merupakan alat yang sangat diperlukan dalam rangka menunjang proses belajar mengajar di sekolah (Hakim, 2005; Oktiani, 2017).

Kemampuan dan keterampilan guru baik menggunakan maupun mengadakan media pembelajaran dalam proses belajar mengajar di dalam kelas bukan lagi merupakan suatu hal yang dapat diabaikan, akan tetapi ini merupakan suatu keharusan, mengingat dalam era pembangunan pendidikan di masa sekarang dan mendatang bertitik tolak pada kualitas keluarannya (Mahnun, 2012; Susanto, 2014). Mengingat tugas yang diemban guru makin komplek yang dibarengi dengan kecanggihan teknologi pendidikan dewasa ini, guru hendaknya memperluas wawasannya dengan berbagai usaha, baik oleh guru itu sendiri maupun dari pihak luar yang mengacu pada penambahan pengetahuan tentang penggunaan dan pengadaan media pembelajaran setiap pelajaran yang dia asuh (Setiawan, 2017). Dilihat dari penjelasan di atas, jelaslah bahwa media pembelajaran mempunyai nilai yang sangat penting dalam proses belajar mengajar. Namun melihat kenyataan di sekolah masih banyak guru yang belum atau bahkan tidak menggunakan media pembelajaran dalam proses belajar mengajarnya.

Keadaan ini juga dialami oleh guru SD, SMP dan SMA yang ada di Kecamatan Lemong khususnya dan Kabupaten Pesisir Barat pada umumnya, apalagi Kebupaten ini baru terbentuk setelah mengalami pemekaran dari Kabupaten induknya yaitu Kabupaten Lampung Barat. Hal ini akan berpengaruh juga terhadap proses belajar mengajar di sekolah. 


\section{Jurnal Pengabdian Kepada Masyarakat BUGUH}

Dipublikasikan

Badan Pelaksana Kuliah Kerja Nyata

Universitas Lampung

Sekretariat Badan Pelaksana Kuliah Kerja Nyata, Universitas Lampung, Jl. Prof. Dr. Soemantri Brojonegoro No. 1, Bandar Lampung 35145.

Apalagi dengan adanya program sertifikasi bagi guru merupakan salah satu cara yang dapat digunakan sebagai instrumen untuk memotong mata rantai penyebab rendahnya kualitas lulusan sekolah. Idealnya sertifikasi profesi guru dilakukan pada saat guru mulai memulai karirnya, sehingga diharapkan mereka mempunyai kompetensi profesional yang sesuai dengan perubahan dan tantangan jaman, sekaligus untuk menepis adanya anggapan bahwa rendahnya mutu pembelajaran yang berdampak pada rendahnya lulusan disebabkan oleh guru yang kurang profesional, maka pemerintah saat ini sedang menggalakkan program sertfikasi guru (Nahdi, dkk., 2020).

Salah satu komponen yang dinilai dalam program sertifikasi ini adalah pembuatan media pembelajaran (Susilana, dan Riyana, 2008) dan guru-guru di SD, SMP dan SMA Kecamatan Lemong Kabupaten Pesisir Barat merasa kesulitan dalam pembuatan media pembelajaran yang menarik terutama dalam pemanfaatan internet untuk mencari sumber pembuatan media dirasa masih kurang.

Secara umum tujuan yang hendak dicapai dalam kegiatan ini adalah: a) untuk meningkatkan pengetahuan guru dalam menyusun media pembelajaran; b) untuk meningkatkan kemampuan guru dalam membuat media pembelajaran; dan c) untuk meningkatkan kemampuan guru dalam menggunakan media pembelajaran. Oleh karena itu, sangat tepat kiranya jika Fakultas Keguruan dan Ilmu Pendidikan Universitas Lampung terpanggil untuk mendampingi guru tersebut dalam kegiatan penyusunan, pembuatan dan penggunaan media pembelajaran melalui program pengabdian pada masyarakat yang dikemas dalam bentuk pelatihan ini.

\section{Bahan dan Metode}

Pelatihan penyusunan, pembuatan dan penggunaan media pembelajaran bagi guru SD, SMP dan SMA di kecamatan lemong Kabupaten Pesisir Barat dilakukan atas tuntutan yang diamanatkan dalam Undang-undang Dasar Guru dan Dosen, dimana guru dituntut untuk menjadi profesional. Untuk itu, sebelum dilakukan pelatihan tentang penyusunan, pembuatan dan penggunaan media pembelajaran terlebih dahulu dilakukan analisis kebutuhan, baik secara langsung maupun tidak langsung bagi para guru Sd, SMP, dan SMA di Kecamatan Lemong Kabupaten Pesisir Barat, seperti pada waktu pelatihan dilakukan wawancara dan perbincangan tentang kendala yang dihadapi dalam pembelajaran SD, SMP, dan SMA di sekolah.

Dalam pelaksanaannya, kegiatan pelatihan ini diawali dengan pre test untuk mengetahui tingkat penguasaan awal para peserta. Di samping itu akan membantu dalam kerangka pengelolaan pelatihan sehingga lebih tepat sasaran terutama dalam pembinaan perorangan. Selanjutnya, diberikan pembekalan pelatihan oleh tim pengabdian dari dosen pendidikan geografi, Pendidikan Sejarah, dan Pendidikan Penjaskesrek dengan menggunakan metode ceramah dan pembuatan media sesuai dengan jadwal yang telah ditentukan. Selama proses pembekalan yang dilakukan secara dialogis dan interaktif.

Pelatihan ini lebih banyak praktek dari pada teori. Setelah diberikan pembekalan secara tatap muka, para peserta diberikan latihan penyusunan, pembuatan, dan penggunaan media pembelajaran sebagai sumber belajar.

Kegiatan pelatihan ini dilaksanakan dengan menggunakan metode berikut:

1. Metode Ceramah

Metode ceramah, yaitu dengan memberikan penjelasan dengan berbicara, agar para guru memperoleh pengetahuan atau wawasan media pembelajaran yang digunakan dalam proses belajar mengajar di sekolah. Metode ini digunakan untuk menyampaikan materi pelatihan yang bersifat kognitif seperti teori, konsep, prinsip serta langkah dalam menyusun, membuat dan menggunakan media pembelajaran. Dalam pelakasanaan metode ini digunakan waktu sebanyak $40 \%$ untuk ceramah atau penyampaian materi, sedangkan sisanya $60 \%$ digunakan untuk diskusi dan tanya jawab.

2. Metode Pembimbingan dan Pelatihan 


\section{Jurnal Pengabdian Kepada Masyarakat BUGUH}

Dipublikasikan

Badan Pelaksana Kuliah Kerja Nyata

Universitas Lampung

Sekretariat Badan Pelaksana Kuliah Kerja Nyata, Universitas Lampung, J. Prof. Dr. Soemantri Brojonegoro No. 1, Bandar Lampung 35145.

Dalam metode ini, kegiatan utama yang dilaksanakan adalah pembimbingan dan pelatihan bagi peserta untuk menerapkan atau mengaplikasikan materi-materi yang telah disampaikan sebelumnya. Kegiatan ini antara lain berupa pembimbingan dan pelatihan tentang cara menyusun, membuat dan menggunakan media pembelajaran. Dalam pelaksanaan metode ini digunakan waktu sebanyak $70 \%$ untuk pembimbingan dan pelatihan, sedangkan 30\% digunakan unntuk diskusi dan tanya jawab.

\section{Hasil dan Pembahasan dan Hasil}

Untuk mengetahui sejauhmana pelatihan ini dapat berjalan dengan baik dan bermanfaat bagi para peserta dapat dilihat dari hasil evaluasi awal, evaluasi proses, dan evaluasi akhir. Sedangkan untuk mengetahui kelancaran selama pelatihan dapat digambarkan bagaimana berlangsungnya kegiatan. Setelah pembukaan dilakukan pada pukul 08.00 WIB, kegiatan dilanjutkan dengan penyampaian materi awal yaitu teori tentang media pembelajaran, Fungsi dan aplikasi media, dan media sebagai sumber pembelajaran bagi guru SD, SMP, dan SMA sampai pada materi terakhir yaitu latihan menyusun, membuat dan menggunakan media sebagai sumber pembelajaran di Sekolah.

Berdasarkan pemantauan dan pengamatan para penyaji materi selama berlangsungnya kegiatan pelatihan dapat disimpulkan bahwa animo dan perhatian para peserta terhadap materi yang disampaikan cukup tinggi. Hal ini dapat dilihat dari banyaknya pertanyaan yang diajukan oleh para peserta pelatihan. Pertanyaan yang diajukan bukan hanya menyangkut media tetapi bagaimana aplikasinya terhadap dunia pendidikan SD, SMP, dan SMA pada khususnya dan pada dunia kerja pada umumnya. Suatu contoh pertanyaan yang diajukan oleh salah seorang peserta pelatihan yaitu: bagaimana media pembelajaran dapat diterapkan diberbagai bidang ilmu pengetahuan, mengingat banyaknya aplikasi yang dapat diterapkan dari penyusunan, pembuatan dan penggunaan media pembelajaran. Kemudian pertanyaan lain yang serupa diajukan adalah bagaimana cara membuat media pembelajaran terutama mengambil media dari internet dan bagaimana bila internet susah untuk diakses sehingga dapat digunakan untuk disiplin mata pelajaran lainnya, contoh: membuat media untuk materi SD yang saat ini tematik berdasarkan kurikulum 2013. Masih banyak lagi pertanyaan yang diajukan oleh para peserta pelatihan sehingga suasana pelatihan menjadi hidup dan tidak monoton.

Dapat dikemukakan bahwa pada umumnya para peserta belum pernah mendapatkan pelatihan tentang khusus tentang penyusunan, pembuatan dan penggunaan media pembelajaran, apalagi mereka berada di daerah yang jauh dari pusat ibukota dan listrik yang tidak tersedia. Pelatihan ini di harapkan dapat di aplikasi diberbagai disiplin ilmu, yang berfungsi untuk meningkatkan kualitas proses belajar mengajar sehingga hasil belajar siswa akan lebih baik. Berdasarkan analisis situasi terdahulu serta wawancara dengan pihak pengelola sekolah dan guru saat dilaksanakan PLPG dapat disimpulkan bahwa pada umumnya guru SD, SMP dan SMA di Kabupaten Pesisir Barat belum pernah seluruhnya mendapatkan pelatihan tentang penyusunan, pembuatan, dan penggunaan media pembelajaran di sekolah. Hal ini disebabkan karena selama ini belum pernah ada kegiatan sejenis diselenggarakan di sekolaah tersebut secara umum, sedangkan pemerintah saat ini melalui sertifikasi guru yang salah satunya untuk mendapat sertifikat guru yang profesional adalah penyusunan, pembuatan, dan penggunaan media pembelajaran di sekolah. Setelah mengetahui pokok permasalahan di atas, maka diadakan kegiatan tersebut. untuk lebih jelasnya keadaan awal dan keadaan akhir yang diharapkan dari perilaku guruguru peserta dapat dilihat pada Tabel 1. 


\section{Jurnal Pengabdian Kepada Masyarakat}

BUGUH

Dipublikasikan

Badan Pelaksana Kuliah Kerja Nyata Universitas Lampung

Sekretariat Badan Pelaksana Kuliah Kerja Nyata, Universitas Lampung, J. Prof. Dr. Soemantri Brojonegoro No. 1, Bandar Lampung 35145.

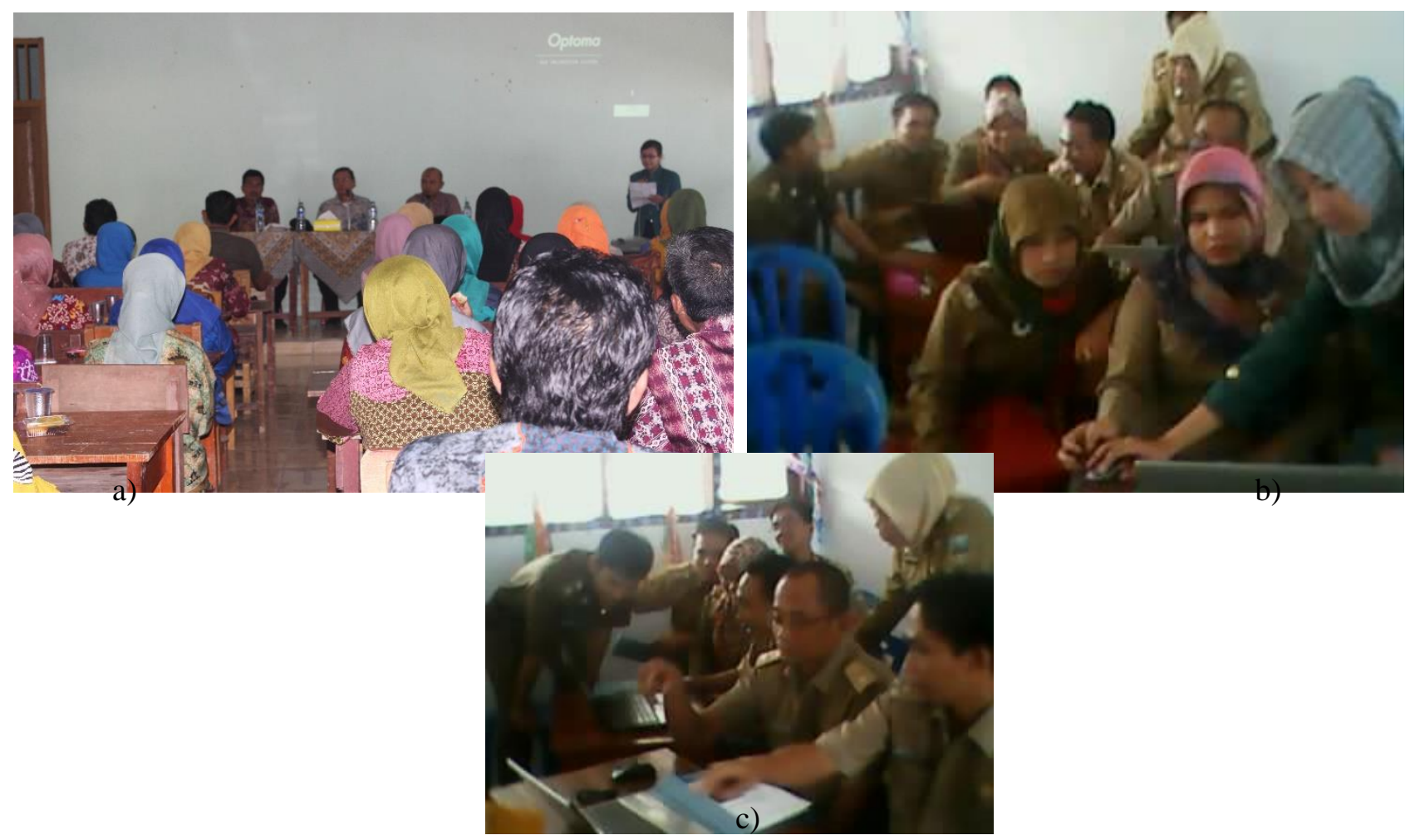

Gambar 1. a) Acara pembukaan oleh Kepala UPTD; b) pendampingan aktivitas pembuatan media pembelajaran; c) peserta sedang melakukan proses pembuatan media pembelajaran

Tabel 1. Keadaan awal dan keadaan akhir yang diharapkan dari guru peserta Pelatihan.

\begin{tabular}{llll}
\hline No & \multicolumn{1}{c}{ Keadaan Awal } & \multicolumn{1}{c}{ Perlakuan } & \multicolumn{1}{c}{ Keadaan Akhir } \\
\hline 1 & $\begin{array}{l}\text { Guru peserta kurang } \\
\text { menguasai pengetahuan } \\
\text { yang tentang media } \\
\text { pembelajaran }\end{array}$ & $\begin{array}{l}\text { Pemberian materi } \\
\text { tentang teori-teori, } \\
\text { konsep, media } \\
\text { pembelajaran }\end{array}$ & $\begin{array}{l}\text { Guru peserta dapat mengetahui, memahami } \\
\text { dan menguasai teori, konsep, prinsip } \\
\text { pembuatan media pembelajaran }\end{array}$ \\
\hline 2 & $\begin{array}{l}\text { Guru peserta belum dapat } \\
\text { membuat media } \\
\text { pembelajaran }\end{array}$ & $\begin{array}{l}\text { Latihan membuat media } \\
\text { pembelajaran }\end{array}$ & $\begin{array}{l}\text { Guru peserta mampu membuat media } \\
\text { pembelajaran }\end{array}$ \\
\hline 3 & $\begin{array}{l}\text { Guru peserta belum dapat } \\
\text { menggunakan media } \\
\text { pembelajaran }\end{array}$ & $\begin{array}{l}\text { Latihan menggunakan } \\
\text { media pembelajaran }\end{array}$ & $\begin{array}{l}\text { Guru peserta dapat menggunakan media } \\
\text { pembelajaran }\end{array}$ \\
\hline
\end{tabular}

\section{Sumber: Hasil Diskusi dengan Kepala Sekolah, Tahun 2019.}

Berdasarkan tabel di atas dapat dilihat bahwa kemampuan guru dalam menyusun, membuat dan memproduksai media pembelajaran masih rendah, apalagi media tersebut harus disesuaikan dengan kurikulum 2013. 


\section{Jurnal Pengabdian Kepada Masyarakat BUGUH}

Dipublikasikan

Badan Pelaksana Kuliah Kerja Nyata

Universitas Lampung

Sekretariat Badan Pelaksana Kuliah Kerja Nyata, Universitas Lampung, Jl. Prof. Dr. Soemantri Brojonegoro No. 1, Bandar Lampung 35145.

\section{Pembahasan}

Kegiatan pelatihan ini ditujukan untuk menjelaskan tentang arti pentingnya penyusunan, pembautan dan penggunaan media pembelajaran sebagai sumber pembelajaran di SD, SMP, dan SMA, menjelaskan tentang fungsi media pembelajaran, dan menggunakan berbagai jenis media pembelajaran, seperti media visual maupun non visual, sehingga dapat digunakan sebagai sumber pembelajaran untuk masa kini.

Pelatihan ini bukan hanya berguna bagi peserta pelatihan, tetapi juga yang terpenting adalah bermanfaat bagi peningkatan mutu proses belajar mengajar. Melalui pelatihan penyusunan, pembuatan dan penggunaan media pembelajaran sebagai sumber pembelajaran di SD, SMP, dan SMA. Sehingga di harapkan para peserta dapat memecahkan permasalahan-permasalahan yang dihadapinya di kelas pada saat proses belajar mengajar berlangsung, serta mampu berupaya untuk mencari solusi yang terbaik. Khusus tentang materi pelatihan, para peserta selama ini belum pernah mengikuti kegiatan yang serupa, meskipun mereka sudah mengikuti bimbingan teknis yang diadakan oleh LPMP.

Dengan adanya pelatihan ini para peserta dapat lebih memahami tentang media pembelajaran, fungsi media, bagaimana media tersebut digunakan sebagai sumber pembelajaran di sekolahnya masing-masing. Untuk dapat menyusun, membuat dan menggunakan media sebagai sumber pembelajaran, peserta dibimbing lebih intensif dalam pelaksanaan pelatihan ini oleh instruktur yang memberikan pelatihan.

Berdasarkan kelompok materi yang disampaikan kepada para peserta pelatihan diperoleh hasil sebagai berikut:

1. Untuk kelompok materi yang bersifat pemahaman atau sikap, para peserta dengan semangat mengikuti pelatihan dan mendengarkan dengan semangat, hal ini terbukti pada saat pelatihan berlangsung maupun saat istirahat selesai peserta masih terus mengikuti pelatihan sampai pelatihan ditutup.

2. Untuk kelompok materi bersifat penguasaan keterampilan praktis, sampai berakhirnya pelatihan ini belum dapat diketahui secara pasti, karena untuk mengetahui tingkat keterampilan dalam menyusun, membuat dan menggunakan media pembelajaran para peserta secara nyata dalam praktek dibutuhkan waktu yang panjang melalui pemantauan di lapangan.

3. Untuk kelompok materi yang bersifat aspek pengetahuan atau kognitif tentang teori-teori media pembelajaran dan fungsinya, para peserta yang memperoleh nilai cukup baik pada saat pre test hanya mencapai 8 orang atau $9,41 \%$ dari 85 orang peserta. Setelah mengikuti pelatihan berdasarkan hasil post test yang dilakukan, peserta yang memperoleh nilai cukup baik sebanyak 65 orang atau 76,47\%. Dengan demikian diperoleh hasil atau peningkatan sebanyak 57 orang atau $67,05 \%$ dari seluruh peserta. Karena materi ini cukup penting dalam menunjang tugas guru dan masih baru bahkan belum pernah diperoleh pelatihan serupa sebelumnya, tentunya banyak peserta yang semangat terhadap pelatihan ini.

Dalam evaluasi akhir, penilaian yang dapat dilakukan hanya sebatas sejauhmana para peserta dapat menyusun media sesuai dengan materi kelas yang diajarkan, membuat media, dan menggunakan dalam hal ini adalah mencetak media hasil pelatihan meskipun hanya diwakilkan oleh beberapa peserta berdasarkan tingkatan sekolah, SD, SMP, dan SMA.

\section{Faktor Pendukung dan Faktor Penghambat \\ 1. Faktor Pendukung}

Adapun faktor-faktor yang mendukung demi kelancaran dan keberhasilan pelatihan ini adalah:

1. Adanya kerjasama yang baik diantara sesama peserta dan sesama anggota tim, mulai dari perencanaan hingga pelaksanaan pelatihan ini.

2. Cukup memadainya sarana dan prasarana berupa alat dan bahan pelatihan berupa LCD, laptop, dan media yang telah disiapkan. 


\section{Jurnal Pengabdian Kepada Masyarakat BUGUH}

Dipublikasikan

Badan Pelaksana Kuliah Kerja Nyata

Universitas Lampung

Sekretariat Badan Pelaksana Kuliah Kerja Nyata, Universitas Lampung, J. Prof. Dr. Soemantri Brojonegoro No. 1, Bandar Lampung 35145.

\section{Faktor Penghambat}

1. Sulitnya mencari waktu yang tepat sehingga memungkinkan semua guru-guru SD, SMP, dan SMA seKecamatan Lemong Kabupaten Pesisir Barat untuk dapat mengikuti pelatihan ini, hal ini disebabkan karena guru-guru masih banyak terlibat proses belajar mengajar di sekolahnya.

2. Masih adanya peserta yang belum begitu paham tentang teori media dan fungsinya. Hal ini disebabkan karena masih ada diantara mereka yang belum mengenal dengan aik teknologi komputer. Serta belum seluruh peserta pernah mengikuti perlatihan serupa, baik yang diadakan oleh Dinas Pendidikan setempat, ataupun perguruan tinggi sebelumnya.

Dengan menggunakan media pembelajaran akan mewujudkan situasi belajar mengajar yang efektif sehingga minat, perhatian dan aktivitas belajar siswa meningkat dan sudah barang tentu hal ini menimbulkan prestasi belajar siswa menjadi baik (Faruqi; Firdianti, 2018). Contoh: Untuk menerangkan perkembangan pendapatan penduduk Lampung dari tahun ke tahun cukup menggunakan grafik atau tabel. Dengan menggunakan alat peraga atau media pembelajaran diharapkan tidak akan timbul salah pengertian atau salah tafsir dari siswa terhadap terhadap apa yang telah disampaikan oleh guru, karena siswa dapat melihat secara langsung dan nyata. Contoh: Untuk mengetahui pembagian tiga wilayah waktu Indonesia dapat digunakan peta Indonesia.

Media pembelajaran dapat mewujudkan pelajaran yang diberikan secara lebih kongkrit atau riil (Susilana, dan Riyana, 2008). Jadi siswa tidak hanya menghafal kata-kata saja tanpa mengetahui makna dari kata-kata tersebut. Dengan demikian akan mendorong perhatian dan dapat menumbuhkan pemikiran berencana dan sistematis. Contoh: Untuk menjelaskan benda-benda purba di museum cukup menampilkan gambar-gambar. Dengan beraneka ragamnya media pembelajaran yang digunakan oleh guru dalam melengkapi metode ceramahnya, akan membangkitkan minat dan motivasi belajar siswa (Abdullah, 2012; Sumiharsono dan Hasanah, 2017). Hal ini akan merangsang siswa untuk lebih giat belajar sehingga dapat mendorong prestasi belajar siswa. Contoh: Untuk mengetahui letak garis lintang dan garis bujur suatu benua dapat menggunakan globe.

Jika kita menggunakan media pembelajaran maka pelajaran mudah dimengerti sehingga menghemat waktu belajar, karena media ini merupakan sarana komunikasi yang efisien dan efektif (Purba, dkk., 2020). Contoh: Data yang seharusnya panjang lebar, seperti data tentang tingkat pertumbuhan produksi perusahaan dapat diperlihatkan secara singkat dengan tabel dan diagram. Dengan menggunakan berbagai macam media pembelajaran akan dapat menambah kegiatan balajar siswa, sehingga menciptakan kreativitas siswa dan membuat pelajaran menjadi lebih menarik dan mantap. Contoh: Siswa disuruh guru mengamati terjadinya gerhana matahari atau turut melukis gambar peredaran bulan yang dipergakan guru.

Pemakaian media pembelajaran dengan contoh yang kongkrit akan menjadikan bahan pelajaran lebih lama melekat dalam ingatan dan pikiran siswa. Contoh: Untuk mengetahui peristiwa tejadinya hujan dapat disajikan dengan gambar-gambar. Guru tidak cukup hanya memiliki pengetahuan tentang media saja, akan tetapi juga harus memiliki keterampilan memilih dan menggunakan media tersebut dengan baik.Untuk itu ia perlu mengalami latihan-latihan praktik secara kontinu dan sistematis, baik dalam re-service maupun dalam in service training. Penggunaan media didalam proses belajar mengajar tidak bermaksud menganti cara mengajar yang baik, meainkan untuk melengkapi dan membantu para guru dalam menyampaikan materi pembelajaran.Dengan mengunakan media diharapkan terjadi interaksi antara guru dengan siswa secara maksimal sehingga dapat mencapai hasil belajar yang sesuai dengan tujuan. 


\section{Jurnal Pengabdian Kepada Masyarakat BUGUH}

Dipublikasikan

Badan Pelaksana Kuliah Kerja Nyata

Universitas Lampung

Sekretariat Badan Pelaksana Kuliah Kerja Nyata, Universitas Lampung, Jl. Prof. Dr. Soemantri Brojonegoro No. 1, Bandar Lampung 35145.

\section{Kesimpulan}

Berdasarkan hasil pembahasan dari pelatihan yang telah dilakukan dapat disimpulkan bahwa:

1. Tingkat pemahaman berupa sikap, para peserta dengan semangat mengikuti pelatihan dan mendengarkan dengan semangat, hal ini terbukti pada saat pelatihan berlangsung maupun saat istirahat selesai peserta masih terus mengikuti pelatihan sampai pelatihan ditutup.

2. Tingkat pemahaman berupa penguasaan keterampilan praktis, sampai berakhirnya pelatihan ini belum dapat diketahui secara pasti, karena untuk mengetahui tingkat keterampilan dalam menyusun, membuat dan menggunakan media pembelajaran.

3. Untuk kelompok materi yang bersifat aspek pengetahuan atau kognitif tentang teori-teori media pembelajaran dan fungsinya, para peserta yang memperoleh nilai cukup baik pada saat pre test hanya mencapai 8 orang atau $9,41 \%$ dari 85 orang peserta. Setelah mengikuti pelatihan berdasarkan hasil post test yang dilakukan, peserta yang memperoleh nilai cukup baik sebanyak 65 orang atau 76,47\%. Dengan demikian diperoleh hasil atau peningkatan sebanyak 57 orang atau 67,05\% dari seluruh peserta. Karena materi ini cukup penting dalam menunjang tugas guru dan masih baru bahkan belum pernah diperoleh pelatihan serupa sebelumnya, tentunya banyak peserta yang semangat terhadap pelatihan ini.

\section{Saran}

Berdasarkan kesimpulan di atas dapat disarankan:

1. Untuk guru

Dibutuhkan pelatihan dan pengulangan dalam menyusun, membuat, dan menggunakan media pembelajaran.

2. Untuk dinas pendidikan

Seringnya dilakukan pelatihan dan mengikuti pelatihan secara rutin untuk setiap guru.

\section{Ucapan Terima Kasih}

Terima kasih diucapkan kepada seluruh komponen yang terlibat baik dari institusi dalam hal ini Ketua LP2M Universitas Lampung, Pemerintah Daerah Kabupaten Pesisir Barat dalam hal ini Kepala Dinas Pendidikan dan Kebudayaan Kabupaten Pesisir Barat.

\section{Daftar Pustaka}

Abdullah, R. (2012). Pembelajaran berbasis pemanfaatan sumber belajar. Jurnal Ilmiah Didaktika: Media Ilmiah Pendidikan dan Pengajaran, 12(2).

Alwi, S. (2017). Problematika guru dalam pengembangan media pembelajaran. ITQAN: Jurnal Ilmu-Ilmu Kependidikan, 8(2), 145-167.

Anshori, S. (2018). Pemanfaatan Teknologi Informasi Dan Komunikasi Sebagai Media Pembelajaran. CivicCulture: Jurnal Ilmu Pendidikan PKn dan Sosial Budaya, 2(1).

Duludu, U. A. (2017). Buku ajar kurikulum bahan dan media pembelajaran pls. Deepublish.

Ekayani, P. (2017). Pentingnya penggunaan media pembelajaran untuk meningkatkan prestasi belajar siswa. Jurnal Fakultas Ilmu Pendidikan Universitas Pendidikan Ganesha Singaraja, 2(1), 1-11.

Faruqi, D. (2018). Upaya meningkatkan kemampuan belajar siswa melalui pengelolaan kelas. Evaluasi: Jurnal Manajemen Pendidikan Islam, 2(1), 294-310.

Firdianti, A. (2018). Implementasi manajemen berbasis sekolah dalam meningkatkan prestasi belajar siswa. Gre Publishing.

Hakim, T. (2005). Belajar secara efektif. Niaga Swadaya.

Hardianto, D. (2012). Pengembangan Media Pembelajaran Berbasis Komputer. Majalah Ilmiah Pembelajaran. Hasanah, U. (2019). Pengaruh Media Pop Up Book Terhadap Hasil Belajar Siswa Pada Mata Pelajaran Ipa Kelas V Sd Negeri 99 Kota Bengkulu (Doctoral dissertation, IAIN BENGKULU). 


\section{Jurnal Pengabdian Kepada Masyarakat}

\section{BUGUH}

Dipublikasikan

Badan Pelaksana Kuliah Kerja Nyata

Universitas Lampung

Sekretariat Badan Pelaksana Kuliah Kerja Nyata, Universitas Lampung, J. Prof. Dr. Soemantri Brojonegoro No. 1, Bandar Lampung 35145.

Luthfi, A. (2008). Pemanfaatan Teknologi Web Sebagai Media Interaktif dan Pengaruhnya Terhadap Minat Belajar bagi Mahasiswa.

Nahdi, D. S., Rasyid, A., \& Cahyaningsih, U. (2020). Meningkatkan kompetensi profesional guru melalui pengembangan media pembelajaran berbasis teknologi informasi. BERNAS: Jurnal Pengabdian Kepada Masyarakat, 1(2), 76-81.

Oktiani, I. (2017). Kreativitas Guru dalam Meningkatkan Motivasi Belajar Peserta Didik. Jurnal Kependidikan, 5(2), 216-232.

Purba, R. A., Tamrin, A. F., Bachtiar, E., Makbul, R., Rofiki, I., Metanfanuan, T., ... \& Ardiana, D. P. Y. (2020). Teknologi Pendidikan. Yayasan Kita Menulis.

Suardi, M. (2018). Belajar \& pembelajaran. Deepublish. Yogyakarta.

Sumiharsono, R., \& Hasanah, H. (2017). Media Pembelajaran: Buku Bacaan Wajib Dosen, Guru dan Calon Pendidik. Pustaka Abadi.

Susanto, A. (2014). Pengembangan pembelajaran IPS di SD. Kencana. Jakarta.

Susilana, R., \& Riyana, C. (2008). Media pembelajaran: hakikat, pengembangan, pemanfaatan, dan penilaian. CV. Wacana Prima.

Winarno Surakhmad, (1980). Pengantar Interaksi Mengajar Belajar, Dasar dan Teknik Metodologi Pembelajaran. Tarsito, Bandung. 